\title{
Investigation of Caspase 9 Gene Polymorphism in Patients With Non-small Cell Lung Cancer
}

\author{
SINA ERCAN ${ }^{1}$, SIBEL ARINC ${ }^{2}$, SEDA GULEC YILMAZ ${ }^{3}$, \\ CIGDEM ALTUNOK $^{4}$, FERIDE YAMAN ${ }^{2}$ and TURGAY ISBIR ${ }^{5}$ \\ ${ }^{1}$ Department of Thoracic Surgery Faculty of Medicine, Yeditepe University, Istanbul, Turkey; \\ ${ }^{2}$ Süreyyapaşa Chest Disease and Thoracic Surgery Training and Research Hospital, Istanbul, Turkey; \\ ${ }^{3}$ Department of Molecular Medicine, Institute of Health Sciences, Yeditepe University, Istanbul, Turkey; \\ ${ }^{4}$ Department of Biostatistics and Medical Informatics, Faculty of Medicine, Yeditepe University, Istanbul, Turkey; \\ ${ }^{5}$ Department of Medical Biology, Faculty of Medicine, Yeditepe University, Istanbul, Turkey
}

\begin{abstract}
Background/Aim: Non-small cell lung cancer (NSCLC) is one of the most common forms of lung cancer and the leading cause of cancer-related deaths in the world. Caspase 9 (CASP9) plays a central role in the intrinsic apoptotic pathway. The aim of the study was to investigate the role of caspase 9 gene polymorphism in patients with non-small cell lung cancer. Materials and Methods: The study included 96 NSCLC cases and 67 controls. CASP9 Ex5+32 G>A polymorphism was investigated by real-time polymerase chain reaction. Results: There was a significant difference between the groups in the frequency of CASP9 genotypes $(p=0.008)$. The number of the carriers of the ancestral GG genotype, was significantly higher in the NSCLC group than in the control $(p=0.009)$. The heterozygote GA genotype and mutant A allele frequency were significantly higher in the control group compared to the NSCLC group ( $p=0.005, p=0.009$, respectively). Serum CASP9 levels were significantly lower in the patients group than in the control group $(p<0.0001)$. Conclusion: CASP9 $E x 5+32 G G$ genotype was a risk factor whereas the variant $A$ allele could be a risk-reducing factor for NSCLC.
\end{abstract}

Non-small cell lung cancer (NSCLC) is the most common type of lung cancer and is the one of the leading causes of death in the world (1). Approximately $85 \%$ of lung cancers are NSCLC and mostly detected at an advanced stage with poor treatment outcome and survival time (2). Classical chemotherapy is the major treatment for advanced NSCLC, but mortality rates remain high (3). Thus new therapeutic

Correspondence to: Sina Ercan, MD, Department of Thoracic Surgery, Faculty of Medicine, Yeditepe University, Koşuyolu Mah. Koşuyolu Cad. No: 168, 34718 Kadıköy, Istanbul, Turkey. Tel: +90 2165785000, e-mail: sercan@yeditepe.edu.tr

Key Words: Non-small cell lung cancer, caspase 9, polymorphism. and preventive strategies based on molecular and genetic analyses are needed (3).

The term "caspase" defines "cysteine-dependent aspartatespecific protease' activity which cleaves high-affinity cysteine residues from aspartate residues in target proteins (4). CASP9, a member of that caspase protein family, regulates programmed cell death named as intrinsic pathway (5). In this pathway, apoptosis is initiated by the release of cytochrome $c$ from mitochondria in response to DNA damage or oxidative stress. Cytochrome $\mathrm{c}$ reacts with the apoptosome, that consists of activating factor 1 (Apaf-1), procaspase- 9 and deoxyadenosine triphosphate (dATP). This multiprotein complex triggers a cascade of effector caspases. Activated $C A S P$ 9, as an initiator caspase, regulates the effector caspases caspase 3 and caspase 7 and executes apoptosis $(6,7)$.

Single nucleotide polymorphisms (SNPs) are the most common variations in the human genome and it has been shown that some SNPs are associated with the pathogenesis of various cancers via regulating gene expression and protein synthesis (8). Apoptotic mechanisms may also be affected by caspase gene polymorphisms as a consequence of altered enzymatic functions (9). Determination of genetic variations of the caspase gene has shown that there could be an association between caspase deregulation and cancer susceptibility (10). However, while the direct functional effects of $C A S P 9$ variants remain unclear, many studies have focused on $C A S P 9$ variants and their role in apoptosis and cancer predisposition $(11,12)$. Therefore, this study aimed to investigate the possible role of $C A S P 9$ variations in NSCLC in the Turkish population.

\section{Materials and Methods}

Study population. This hospital-based case-control study was conducted prospectively and all participants were recruited from Süreyyapaşa Chest Disease and Thoracic Surgery Training and Research Hospital and the Department of Thoracic Surgery in Yeditepe University Hospital, Istanbul, Turkey. Ninety-six patients 
with NSCLC and 67 healthy controls were selected after clinical examination. Pathological investigations of patients were determined according to World Health Organization Classification of Lung Tumors (13). Approval of the study was obtained from the Medical Ethics Committee of Yeditepe University (Approval no:591, date:20.04.2016). Demographic and clinical characteristics of all patients were obtained from the medical records of the hospital and patients' clinical data were followed-up prospectively.

Genetic analysis. After obtaining an informed consent from the partipiciants, peripheral blood samples were collected into ethylenediaminetetraacetic acid (EDTA) coated polystyrene tubes. DNA extraction was performed by iPrep Purification Instrument (Invitrogen, Life Technologies, Carlsbad, CA, USA) by using $350 \mu \mathrm{l}$ of whole blood and Invitrogen iPrep PureLink gDNA blood isolation kit (Invitrogen, Life Technologies). The concentration of the isolated DNA samples was determined spectrophotometrically with the NanoDrop 2000 (Thermoscientific, Waltham, MA, USA), 1.7-1.9 optical density range were taken for genotyping. CASP9 gene Ex $5+32$ $\mathrm{G}>\mathrm{A}$ (rs1052576) polymorphism was analyzed by Applied Biosystems 7500 Fast Real Time PCR instrument (Applied Biosystems, Foster City, CA, USA) by using TaqMan Genotyping Assay and TaqMan Genotyping Master Mix (TaqMan Reagents, Applied Biosystems). Reaction mixture and conditions were carried out according to the manufacturer's instructions.

Determination of serum CASP9 Levels. Peripheral blood samples collected into sterile $8 \mathrm{ml}$ vacuum gel blood collection tubes and allowed to clot for $15 \mathrm{~min}$ at room temperature. Then serum was separated by centrifugation. The serum samples were put into eppendorf tubes and stored at $-80^{\circ} \mathrm{C}$ until testing. Serum CASP 9 levels were determined by enzyme-linked immunoassay (ELISA) (Poweam Medical Co. Nanjing City, Jiangsu Province, China).

Statistical analysis. Statistical analyses were performed using SPSS Ver. 23 software (SPSS Inc, Chicago, IL, USA). Data are reported as mean \pm standard deviation (SD) or number and percentage. The significance of the differences between groups were examined by Student's $t$-test, in case of variables that were not normally distributed, and the Mann-Whitney $U$-test was used to compare the groups. Chi square and Fisher's exact tests were used to evaluate the difference in the existence of the CASP9 Gene Ex5+32 G>A (rs1052576)) polymorphism in the patient and control groups. Power of analysis was evaluated with post-hoc power analysis. Risk estimations were examined with odds ratio (OR) at $95 \%$ confidence interval $(\mathrm{CI}), p<0.05$ denoted as statistically significant.

\section{Results}

The demographic characteristics of NSCLC and control groups are given in Table I. The analysis included 96 patients with NSCLC and 67 healthy control subjects aged $61.25 \pm 10.62$, and $60.79 \pm 8.27$ years, respectively. No significant difference was found between NSCLC and control groups in terms of median age $(p=0.755)$. Moreover there was no significant difference with regards to gender between study groups $(p=0.555)$. There was significant difference between active smokers and non-smokers, between the groups $(p<0.0001)$.
Table I. Demographic characteristics of the study population.

\begin{tabular}{|c|c|c|c|c|c|}
\hline & \multicolumn{2}{|c|}{ Control } & \multicolumn{2}{|c|}{ NSCLC } & \multirow[t]{2}{*}{$p$-Value } \\
\hline & $\mathrm{n}$ & $\%$ & $\mathrm{n}$ & $\%$ & \\
\hline Total & 67 & 100 & 96 & 100 & \\
\hline Age (years), mean \pm SD & \multicolumn{2}{|c|}{$61.25 \pm 10.62$} & \multicolumn{2}{|c|}{$60.79 \pm 8.27$} & 0.755 \\
\hline Gender (Male/Female) & $9 / 58$ & $13.4 / 86.6$ & $10 / 86$ & $10.4 / 89.6$ & 0.555 \\
\hline \multicolumn{6}{|c|}{ the } \\
\hline$<60$ & 36 & 53.7 & 45 & 46.9 & \multirow[t]{2}{*}{0.389} \\
\hline$\geq 60$ & 31 & 46.3 & 51 & 53.1 & \\
\hline \multicolumn{6}{|l|}{ Smoking Status } \\
\hline Active smoker & 32 & 47.8 & 17 & 17.7 & \multirow{2}{*}{$<0.0001^{*}$} \\
\hline Non-smoker & 35 & 52.2 & 79 & 82.3 & \\
\hline
\end{tabular}

NSCLC: Non-small cell lung cancer; n: number of individuals; SD: standart deviation, ${ }^{*} p$-values less than 0.05 denoted statistical significance.

The genotype and allele frequencies for CASP9 Ex $5+32$ $\mathrm{G}>\mathrm{A}$ polymorphism in NSCLC patients and controls are given in Table II. CASP9 Ex5+32 G>A genotype frequencies between NSCLC group and control group were significantly different $\left(\chi^{2}=9.665 ; p=0.008\right)$.

The frequency of the GG genotype was significantly higher in the NSCLC group than in the controls $\left(\chi^{2}=4.450, p=0.009\right.$, $\mathrm{OR}=2.929, \quad 95 \% \mathrm{CI}=1.285-6.679)$. Also, there were statistically significant correlations between the groups regarding GA genotype $\left(\chi^{2}=7.816, p=0.005, \mathrm{OR}=0.405\right.$, $95 \% \mathrm{CI}=0.214-0.768)$. The AA homozygote genotype did not differ significantly between the groups $\left(\chi^{2}=0.365, p=0.721\right.$, $\mathrm{OR}=1.133, \quad 95 \% \mathrm{CI}=0.620-2.470)$. Ancestral $\mathrm{G}$ allele frequency was not significantly different between the groups $\left(\chi^{2}=0.365, p=0.546, \mathrm{OR}=0.808,95 \% \mathrm{CI}=0.405-1.614\right)$, yet mutant $\mathrm{A}$ allele frequency was significantly higher in the control group $\left(\chi^{2}=4.489, p=0.009, \mathrm{OR}=0.341,95 \% \mathrm{CI}=1.051\right.$ 0.778). These results indicated that carrying variant $A$ allele decreased the NSCLC risk by 2.9 fold (OR=0.341, 95\%CI $=0.150-0.778$ ). Determination of CASP9 Ex $5+32 \mathrm{G}>\mathrm{A}$ polymorphism and histological types in patients with NSCLC showed that neither genotype variants nor allele frequencies were significantly different between groups (Table II).

As shown in Figure 1, CASP9 serum levels were significantly lower in the patient group than in the control $(p<0.0001)$. However, there was no statistically significant difference between the groups regarding $C A S P 9$ serum levels in $C A S P 9$ Ex $5+32 \mathrm{G}>\mathrm{A}$ genotype carriers ( $>0.05$ ).

\section{Discussion}

Apoptosis, also defined as programmed cell death, is a crucial physiological mechanism that controls cell proliferation homeostasis. Dysregulation of apoptosis is an important hallmark in carcinogenesis (14). There are two main apoptotic 
Table II. The distribution of Caspase 9 genotype and allele frequencies in patient and control groups.

\begin{tabular}{|c|c|c|c|c|c|}
\hline & NSCLC (n=96) & Control $(n=67)$ & $p$-Value & Odds Ratio & $95 \% \mathrm{CI}$ \\
\hline Genotype & & & $X^{2}=9,665 ; p=0.008 *$ & & \\
\hline GG & $30(31.3 \%)$ & $9(13.4 \%)$ & $0.009^{*}$ & 2.929 & $1.285-6.679$ \\
\hline GA & $36(37.4 \%)$ & $40(59.7 \%)$ & $0.005^{*}$ & 0.405 & $0.214-0.768$ \\
\hline $\mathrm{AA}$ & $30(31.3 \%)$ & $18(26.9 \%)$ & 0.721 & 1.133 & $0.620-2.470$ \\
\hline Allele & & & Allelic Count & & \\
\hline G & $96(50 \%)$ & $58(43.3 \%)$ & 0.546 & 0.808 & $0.405-1.614$ \\
\hline A & $96(50 \%)$ & $76(56.7 \%)$ & $0.009 *$ & 0.341 & $0.150-0.778$ \\
\hline
\end{tabular}

$\mathrm{n}$ : Number of individuals; OR: odds ratio; CI: confidence interval; $\mathrm{X}^{2}$ : Chi square used for comparison of patients with NSCLC and control group; $*_{p}<0.05$ denotedstatistically significant differences.

pathways the extrinsic (receptor mediated) pathway and the intrinsic (mitochondrial) pathway, which utilize a cascade of enzymes called caspases. Initiator caspases, such as caspase 8 and caspase 10 , trigger the extrinsic pathway, whereas $C A S P 9$ is involved in the intrinsic pathway. The instrinsic pathway is initiated with the release of cytochrome $c$ from the intermembrane space of mitochondria. It forms a multiprotein complex named apoptosome, which consists of cytochrome $c$, apoptotic peptidase activating factor 1 (APAF1), deoxyadenosine triphosphate (dATP) and procaspase 9. $C A S P 9$ is subsequently activated and triggers effector caspases resulting in apoptosis $(15,16)$.

Several studies have evaluated the carcinogenesis risk in $C A S P 9$ gene variations, whose functional effects and clinical implications are still unclear. New studies are needed to determine the functional effects of CASP9 variations and cancer predisposition (17). CASP9 Ex5+32 G>A polymorphism has been reported as a key genetic variation inducing changes in amino acid sequence and altering protein functions (18). Therefore, the present study aimed to investigate the role of CASP9 polymorphism on NSCLC risk.

It has been shown that CASP9 variants change the enzyme's activity, suggesting a relationship between $C A S P 9$ polymorphism and lung cancer risk. Also, a possible correlation between $C A S P 9$ variants and tumor histology has been investigated to determine the genetic etiology of lung cancer. However, no evidence was found regarding the relationship between histological tumor type and CASP9 polymorphisms, however, it has been reported that $C A S P 9$ promoter variations are associated with the risk of lung cancer owing to altered CASP9 enzyme activity (19). In another study, CASP 9 variants have been suggested to have essential roles in apoptosis inhibition and lung cancer susceptibility (20). Combined analysis of CASP9 gene polymorphisms and epxression has revealed the importance of CASP9 polymorphism on the risk of lung cancer. CASP9 allele variation carriers had lower CASP9 levels and apoptotic capacity, therefore had a higher risk of lung cancer

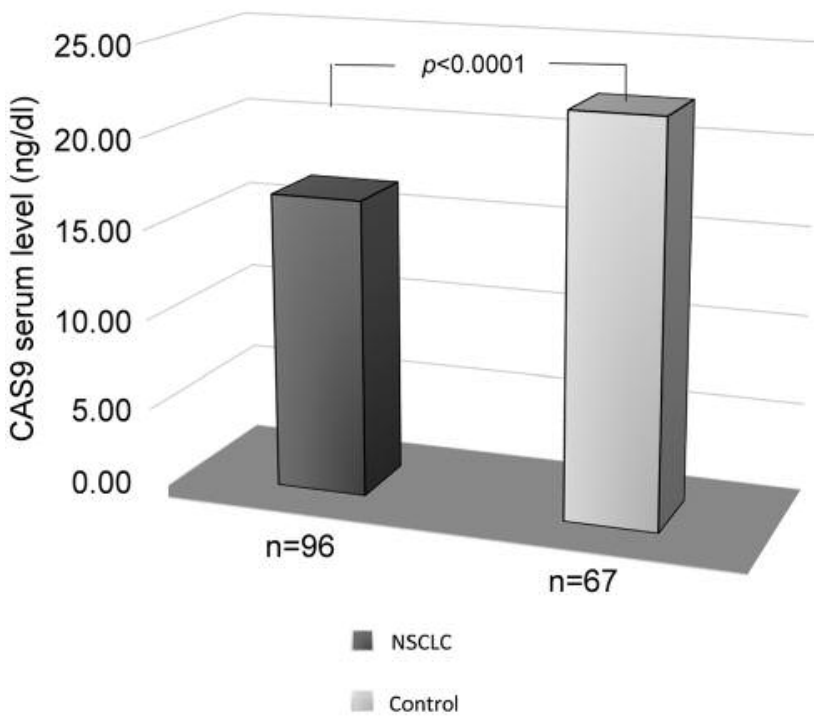

Figure 1. Serum caspase 9 levels of the study populations.

(21). Thus, CASP9 Ex5+32 G>A polymorphism emerges as a remarkable SNP to determine association between gene variations and cancer susceptibility. In the present study, the CASP9 variant A allele was identified as a risk-reducing factor; it caused a 2.9-fold decrease in the NSCLC risk. These results are consistent with a meta-analysis performed by CASP 9 promoter and exon sequence examination on the susceptibility to multiple cancers such as lung, prostate, gastric, colorectal and etc. In this meta-analysis, it has been shown that the CASP9 mutant A variant had a protective effect against various cancers and it was suggested that this effect may originate from increased apoptotic activity. CASP9 Ex5+32 G>A polymorphism could increase apoptosome affinity and decrease cancer risk (22). Although there were no statistically significant differences regarding 
CASP9 Ex $5+32 \mathrm{G}>\mathrm{A}$ genotypes, our results showed that serum $C A S P 9$ levels were significantly higher in the control group than in the patient group.

Another meta-analysis has evaluated functional CASP9 gene polymorphisms in various cancer types and confirmed the protective role of $C A S P 9 \mathrm{Ex} 5+32 \mathrm{G}>\mathrm{A}$ mutant A allele in cancer susceptibility (23). The association between CASP9 genes and hematological malignancies have also been investigated in two case-control studies. Similiar to our results, these studies showed that the homozygote mutant AA and heterozygote GA genotypes associated with decreased risk of multiple myeloma (24) and non-Hodgkin lymphoma (25).

Consequently, the present study showed that reduced serum CASP9 levels were associated with NSCLC risk and carrying CASP9 Ex5+32 G>A mutant A allele was a risk reducing factor, whereas wildtype homozygote GG genotype was having a negative impact on NSCLC. These results suggested that $C A S P 9$ Ex $5+32 \mathrm{G}>\mathrm{A}$ could play an important role in NSCLC susceptibility. To the best of our knowledge, this was the first study that investigate the association between CASP9 Ex $5+32 \mathrm{G}>\mathrm{A}$ polymorphism and NSCLC in a Turkish patient population. Due to the limitations of small sample size, further investigations are needed to display the relationship between $C A S P 9$ gene polymorphisms and NSCLC predisposition.

\section{Conflicts of Interest}

The Authors declare that no conflicts of interest exist.

\section{Authors' Contributions}

Sina Ercan: Recruitment of study participants and clinical investigation, data collection, contributed to the design and implementation of the research. Sibel Arınç, Feride Yaman: recruitment of study participants and clinical investigation, data collection. Seda Gülec Yılmaz: performed the experiments. Çiğdem Altunok: performed statistical analysis. Turgay İsbir: contributed to the design and implementation of the research, writing manuscript, approval of the final version. All Authors read and approved the final manuscript.

\section{References}

1 Ettinger DS., Akerley W, Borghaei H, Chang AC, Cheney RT, Chirieac LR, D'Amico TA, Demmy TL, Ganti AK, Govindan R, Grannis FW Jr, Horn L, Jahan TM, Jahanzeb M, Kessinger A, Komaki R, Kong FM, Kris MG, Krug LM, Lennes IT, Loo BW Jr, Martins R, O’Malley J, Osarogiagbon RU, Otterson GA, Patel JD, Pinder-Schenck MC, Pisters KM, Reckamp K, Riely GJ, Rohren E, Swanson SJ, Wood DE, Yang SC, Hughes M and Gregory KM; NCCN (National Comprehensive Cancer Network): Non-small cell lung cancer. J Natl Compr Canc Netw 10(10): 1236-1271, 2012. PMID: 23054877.

2 Jurišić V, Obradovic J, Pavlović S and Djordjevic N: Epidermal growth factor receptor gene in non-small-cell lung cancer: The 1mportance of promoter polymorphism investigation. Anal Cell Pathol (Amst) 2018: 6192187, 2018. PMID: 30406002. DOI: $10.1155 / 2018 / 6192187$

3 Esposito L, Conti D, Ailavajhala R, Khalil N and Giordano A: Lung cancer: are we up to the challenge? Curr Genomics 11(7): 513-518, 2010. PMID: 21532835 . DOI: $10.2174 / 138920210793175903$

4 Alnemri E, Livingston D, Nicholson D, Salvesen G, Thornberry N, Wong W and Yuan J: Human ICE/CED-3 protease nomenclature. Cell 87: 171, 1996. PMID: 8861900.

5 Murphy BM, O'Neill AJ, Adrain C, Watson RW and Martin SJ: The apoptosome pathway to caspase activation in primary human neutrophils exhibits dramatically reduced requirements for cytochrome C. J Exp Med 197(5): 625-632, 2003. PMID: 12615903.

6 Earnshaw WC, Martins LM and Kaufmann SH: Mammalian caspases: structure, activation, substrates, and functions during apoptosis. Annu Rev Biochem 68: 383-424, 1999. PMID: 10872455. DOI: 10.1146/annurev.biochem.68.1.383

7 Degterev A, Boyce M and Yuan J: A decade of caspases. Oncogene 22(53): 8543-8567, 2003. PMID: 14634618. DOI: 10.1038/sj.onc.1207107

8 Erichsen HC and Chanock SJ: SNPs in cancer research and treatment. Br J Cancer 90(4): 747-751, 2004. PMID: 14970847. DOI: $10.1038 /$ sj.bjc.6601574

9 Pistritto G, Trisciuoglio D, Ceci C, Garufi A and D'Orazi G: Apoptosis as anticancer mechanism: function and dysfunction of its modulators and targeted therapeutic strategies. Aging (Albany NY) 8(4): 603-619, 2016. PMID: 27019364. DOI: 10.18632/ aging.100934

10 Hensley P, Mishra M and Kyprianou N: Targeting caspases in cancer therapeutics. Biol Chem 394(7): 831-843, 2013. PMID: 23509217. DOI: $10.1515 / \mathrm{hsz}-2013-0128$

11 Ekert PG, Read SH, Silke J, Marsden VS, Kaufmann H, Hawkins CJ, Gerl R, Kumar S and Vaux DL: Apaf-1 and caspase-9 accelerate apoptosis, but do not determine whether factor-deprived or drug-treated cells die. J Cell Biol 165: 835842, 2004. PMID: 15210730. DOI: 10.1083/jcb.200312031

12 Marsden VS, O'Connor L, O'Reilly LA, Silke J, Metcalf D, Ekert PG, Huang DC, Cecconi F, Kuida K, Tomaselli KJ, Roy S, Nicholson DW, Vaux DL, Bouillet P, Adams JM and Strasser A: Apoptosis initiated by Bcl-2-regulated caspase activation independently of the cytochrome c/Apaf-1/caspase-9 apoptosome. Nature 419: 634-637, 2002. PMID: 12374983. DOI: 10.1038/ nature 01101

13 Travis WD, Brambilla E, Nicholson AG, Yatabe Y, Austin JHM, Beasley MB, Chirieac LR, Dacic S, Duhig E, Flieder DB, Geisinger K, Hirsch FR, Ishikawa Y, Kerr KM, Noguchi M, Pelosi G, Powell CA, Tsao MS and Wistuba I; WHO Panel: The 2015 World Health Organization classification of lung tumors: 1mpact of genetic, clinical and radiologic advances since the 2004 classification. J Thorac Oncol 10(9): 1243-1260, 2015. PMID: 26291008. DOI: 10.1097/JTO.0000000000000630

14 Ward TH, Cummings J, Dean E, Greystoke A, Hou JM, Backen A, Ranson M and Dive C: Biomarkers of apoptosis. Br J Cancer 99(6): 841-846, 2008. PMID: 19238626. DOI: 10.1038/ sj.bjc.6604519

15 Adrain $\mathrm{C}$ and Martin SJ: The mitochondrial apoptosome: a killer unleashed by the cytochrome seas. Trends Biochem Sci 26(6): 390-397, 2001. PMID: 11406413.

16 Bratton SB and Salvesen GS: Regulation of the Apaf-1-caspase9 apoptosome. J Cell Sci 123(Pt 19): 3209-3214, 2010. PMID: 20844150. DOI: $10.1242 /$ jcs.073643 
17 Cotter TG: Apoptosis and cancer: the genesis of a research field. Nat Rev Cancer 9(7): 501-507, 2009. PMID: 19550425. DOI: $10.1038 / \mathrm{nrc} 2663$

18 Hirano A, Nagai H, Harada H, Haga S, Kajiwara T and Emi M: Two novel single-nucleotide polymorphisms of the Caspase-9 (CASP9) gene in the Japanese population. Genes Immun 2(2): 117-118, 2001. PMID: 11393657. DOI: 10.1038/sj.gene.6363728

19 Park JY, Park JM, Jang JS, Choi JE, Kim KM, Cha SI, Kim CH, Kang YM, Lee WK, Kam S, Park RW, Kim IS, Lee JT and Jung TH: Caspase 9 promoter polymorphisms and risk of primary lung cancer. Hum Mol Genet 15(12): 1963-1971, 2006. PMID: 16687442. DOI: $10.1093 / \mathrm{hmg} / \mathrm{ddl} 119$

20 Lin J, Lu C, Stewart DJ, Gu J, Huang M, Chang DW, Lippman $\mathrm{SM}$ and $\mathrm{Wu} \mathrm{X}$ : Systematic evaluation of apoptotic pathway gene polymorphisms and lung cancer risk. Carcinogenesis 33(9): 16991706, 2012. PMID: 22665367. DOI: 10.1093/carcin/bgs192

21 Lee SY, Choi YY, Choi JE, Kim MJ, Kim JS, Jung DK, Kang HG, Jeon HS, Lee WK, Jin G, Cha SI, Kim CH, Jung TH and Park JY: Polymorphisms in the caspase genes and the risk of lung cancer. J Thorac Oncol 5(8): 1152-1158, 2010. PMID: 20661084. DOI: $10.1097 / J T O .0 b 013 \mathrm{e} 3181 \mathrm{e} 04543$

22 Xu W, Jiang S, Xu Y, Chen B, Li Y, Zong F, Zhao W and Wu J: A meta-analysis of caspase 9 polymorphisms in promoter and exon sequence on cancer susceptibility. PLoS One 7(5): e37443 2012. PMID: 22616010. DOI: 10.1371/journal.pone.0037443
23 Zhang ZY, Xuan Y, Jin XY, Tian X and Wu R: CASP-9 gene functional polymorphisms and cancer risk: a large-scale association study plus meta-analysis. Genet Mol Res 12(3): 30703078, 2013. PMID: 23479167. DOI: 10.4238/2013.February.28.22

24 Hosgood HD 3rd, Baris D, Zhang Y, Zhu Y, Zheng T, Yeager M, Welch R, Zahm S, Chanock S, Rothman N and Lan Q: Caspase polymorphisms and genetic susceptibility to multiple myeloma. Hematol Oncol 26(3): 148-151, 2008. PMID: 18381704. DOI: 10.1002/hon.852

25 Lan Q, Zheng T, Chanock S, Zhang Y, Shen M, Wang SS, Berndt SI, Zahm SH, Holford TR, Leaderer B, Yeager M, Welch R, Hosgood D, Boyle P and Rothman N: Genetic variants in caspase genes and susceptibility to non-Hodgkin lymphoma. Carcinogenesis 4: 823-827, 2007. PMID: 17071630. DOI: $10.1093 /$ carcin/bgl196
Received March 13, 2019

Revised April 15, 2019

Accepted April 16, 2019 